Tropical Journal of Pharmaceutical Research February 2019; 18 (2): 251-256

ISSN: $1596-5996$ (print); 1596-9827 (electronic)

(C) Pharmacotherapy Group, Faculty of Pharmacy, University of Benin, Benin City, 300001 Nigeria.

\title{
Bryostatin inhibits proliferation of ependymoma cells by suppressing expressions of cyclooxygenase-2 and interleukin-8
}

\author{
Weiyuan $\mathrm{Xu}^{1}$, Chengren $\mathrm{Xie}^{2 \star}$, Yuchen Feng ${ }^{3}$ \\ ${ }^{1}$ Department of Orthopedics, Lanzhou University Second Hospital, Lanzhou 730030, ${ }^{2}$ Department of Neurosurgery, Wuwei \\ People's Hospital, Wuwei 733000, ${ }^{3}$ Second Clinical Medical College, Lanzhou University, Lanzhou 730030, China \\ *For correspondence: Email: Clementinavacri@yahoo.com; Tel: 0086-0935-5820285
}

\begin{abstract}
Purpose: To investigate the effect of bryostatin on the proliferation of ependymoma cells, and the underlying mechanism(s).

Methods: Ependymoma cell lines (SC-EPN1 and SC-EPN2) were cultured in Dulbecco's modified Eagle's medium (DMEM) supplemented with $10 \%$ fetal bovine serum (FBS) and streptomycin (10 $\mathrm{mg} / \mathrm{ml}$ ) in a humidified incubator at $37{ }^{\circ} \mathrm{C}$ and $5 \% \mathrm{CO}_{2}$ atmosphere. Rhe cells were randomly assigned to six groups: control group and five bryostatin groups treated with increasing concentrations of bryostatin $(10-50 \mu \mathrm{M})$. Cell proliferation was determined by MTT assay, while real-time quantitative polymerase chain reaction (qRT-PCR) was used to determine the levels of expressions of apoptosisrelated genes. Expressions of cyclooxygenase-2 (COX-2), interleukin-8 (IL-8), BCl-2, Bax and Pglycoprotein were determined using Western blotting.

Results: Treatment with bryostatin significantly and concentration-dependently down-regulated COX-2 and IL-8 mRNAs expressions $(p<0.05)$. On the other hand, proliferation of SC-EPN1 and SC-EPN2 cells were significantly and concentration-dependently inhibited by bryostatin, relative to control group ( $p$ $<0.05)$. After $72 \mathrm{~h}$ of treatment with bryostatin $(50 \mu \mathrm{M})$, the extent of apoptosis was significantly higher in SC-EPN1 $(57.43 \%)$ and SC-EPN2 cells $(52.29 \%)$ than in control group $(2.37 \%, p<0.05)$. The results of Western blotting showed that treatment with bryostatin significantly reduced the expressions of $\mathrm{Bcl}-2$ in ependymoma cells, relative to the control group $(p<0.05)$. However, there were no significant differences in the expression of Bax among the groups $(p>0.05)$. P-glycoprotein expression was significantly higher in bryostatin groups than in control group $(p<0.05)$. The results of flow cytometric analysis of rhodamine-123 (rh123) fluorescence showed that after $72 \mathrm{~h}$ of treatment with bryostatin $(50 \mu \mathrm{M})$, rhl23 fluorescence significantly decreased in SC-EPN1 (8.10\%) and SC-EPN2 cells $(10.11 \%)$, relative to control group $(20.83 \%, p<0.05)$.

Conclusion: Bryostatin exerts anti-proliferative and apoptotic effects on ependymoma cells by suppressing COX-2 and IL-8 expressions. Thus, the inhibition of COX-2 expression may constitute an effective chemotherapeutic strategy for ependymoma treatment.
\end{abstract}

Keywords: Bryostatin, Ependymoma cells, Proliferation, Apoptosis, Expression

This is an Open Access article that uses a funding model which does not charge readers or their institutions for access and distributed under the terms of the Creative Commons Attribution License (http://creativecommons.org/licenses/by/4.0) and the Budapest Open Access Initiative (http://www.budapestopenaccessinitiative.org/read), which permit unrestricted use, distribution, and reproduction in any medium, provided the original work is properly credited.

Tropical Journal of Pharmaceutical Research is indexed by Science Citation Index (SciSearch), Scopus, International Pharmaceutical Abstract, Chemical Abstracts, Embase, Index Copernicus, EBSCO, African Index Medicus, JournalSeek, Journal Citation Reports/Science Edition, Directory of Open Access Journals (DOAJ), African Journal Online, Bioline International, Open-J-Gate and Pharmacy Abstracts 


\section{INTRODUCTION}

Ependymoma is the third most common childhood tumor, and it accounts for $15 \%$ of brain tumors in children [1,2]. It is an intracranial tumor characterized by poor prognosis and 5 year-survival of 40 to $65 \%[3,4]$. Surgical resection is the most commonly used method for treatment of ependymoma [3]. However, the use of chemo- and craniospinal radiotherapy for the treatment of this tumor is just beginning to gain relevance [3]. The expression of multi-drugresistant (MDR) gene against commonly used drugs is the major setback in the treatment of ependymoma [2]. In most brain tumors, there are marked increases in the secretion of prostaglandins [5-7]. Prostaglandins are synthesized from arachidonic acid via the catalytic action of COX-2 which expression is induced by pro-inflammatory cytokines [8]. It is reported that the level of COX-2 in tumors is markedly elevated and its down-regulation inhibits tumor growth and progression [9-12]. High expression of this enzyme in glioma cells is associated with short period of survival, and its inhibition by NS-398 suppresses proliferation and invasion of the cells $[9,12]$. Cyclooxygenase 2inhibiting drugs slow the growth of neuroepithelial tumor cells through induction of apoptosis [11]. Studies have shown that inhibition of COX-2 plays an important role in the treatment of ependymoma. The aim of this study was to investigate the effect of bryostatin on the proliferation of ependymoma cells, and the underlying mechanism(s).

\section{EXPERIMENTAL}

\section{Materials and reagents}

SC-EPN1 and SC-EPN2 cells were obtained from Seoul National University; FBS was purchased from Hyclon (USA), while DMEM was a product of Gibco BRL (USA). EL800 universal microplate reader was purchased from Bio-Tek Instruments Inc. (USA), and 96-well plates were purchased from Falcon (USA). Annexin V/FITC kit and flow cytometer were products of $B D$ Biosciences (USA); protein extraction and bicinchoninic acid (BCA) assay kits were products of Sangon Biotech Co., Ltd., while bovine serum albumin (BSA) and Trizol reagent were obtained from Thermo Fisher Scientific Inc. (USA). P-glycoprotein, COX-2, Bcl-2, Bax, and $\beta$ actin primers were obtained from Santa Cruz Biotechnologies (USA). Horseradish peroxidase-conjugated goat anti-rabbit IgG was a product of Jackson Immuno Research Laboratories Inc. (USA), while chemiluminescence liquid and autoradiography film were purchased from Bio-Rad Laboratories Inc. (USA). Rhodamine 123 from Sigma (USA).

\section{Cell lines and grouping}

The SC-EPN1 and SC-EPN2 cells were cultured at $37^{\circ} \mathrm{C}$ in DMEM supplemented with $10 \%$ FBS and streptomycin $(10 \mathrm{mg} / \mathrm{ml})$ in a humidified incubator containing $5 \%$ CO2. Cells in exponential growth phase were used for this study. In each group of cancer cell line, the cells were randomly assigned to six groups: control group and five bryostatin groups which were treated with increasing concentrations of bryostatin (10 - $50 \mu \mathrm{M})$.

\section{MTT assay}

Cells $\left(5 \times 10^{5}\right.$ cells/well) at exponential growth phase were seeded into 96-well plates containing DMEM. After $24 \mathrm{~h}$ of incubation, the cells were treated with varied concentrations of bryostatin $(10-50 \mu \mathrm{M})$ and cultured for $72 \mathrm{~h}$. This was followed by the addition of $20 \mathrm{ml}$ of $0.5 \%$ MTT solution within $4 \mathrm{~h}$, after which the culture medium was changed. Dimethylsulfoxide (DMSO, (150 $\mu \mathrm{l})$ was added in drops to each well, and the wells were placed on an oscillator for $10 \mathrm{~min}$ to completely dissolve the formazan crystals. The control wells contained culture medium, MTT solution and DMSO only, and were treated same way as the sample wells. Each well was incubated in the dark for $2 \mathrm{~h}$ and absorbance was measured at $570 \mathrm{~nm}$ using an EL800 universal microplate reader. The procedure was performed in triplicate and cell proliferation $(\mathrm{P})$ was calculated as in $\mathrm{Eq} 1$.

$P(\%)=\{(1-A s) / A c\} 100$

where As and Ac are the absorbance of sample and control, respectively.

\section{Apoptosis assay}

The extent of apoptosis in SC-EPN1 and SCEPN2 cells treated with bryostatin (40 and 50 $\mu \mathrm{M})$, and control cells was determined using a flow cytometer. The cells were incubated for 72 $h$, harvested and subsequently treated with HEPES binding buffer containing Annexin V-FITC and PI. The cells were then placed on a flow cytometer and read. The measurements were performed in triplicates and the mean taken.

\section{Western blotting}

The expressions of COX-2, Bcl-2, Bax, and Pglycoprotein in SC-EPN1 and SC-EPN2 cells 
treated with bryostatin (40 and $50 \mu \mathrm{M}$ ) were determined using Western blotting. Ice-cold cell plates were treated with phenylmethylsulfonyl fluoride and phosphatase, and the protein content was extracted using protein extraction kit. The cell suspension was centrifuged at 12 , $000 \mathrm{~g}$ for $45 \mathrm{~min}$, and the protein concentration of the supernatant was determined using BCA assay. A portion of total cell protein $(50 \mu \mathrm{g})$ from each sample was separated on a $12 \%$ sodium dodecyl sulphate (SDS)-polyacrylamide gel electrophoresis and transferred to a fixed polyvinylidene fluoride membrane at $110 \mathrm{~V}$ and $90^{\circ} \mathrm{C}$ for $120 \mathrm{~min}$. Subsequently, $3 \% \mathrm{BSA}$ in Tris-buffered saline containing $0.2 \%$ Tween-20 (TBS-T) was added with gentle shaking at room temperature and incubated to block non-specific binding of the blot. Thereafter, the blot was incubated with primary antibody (1: 500) at $4{ }^{\circ} \mathrm{C}$ overnight.

The membrane was washed thrice with TBS-T and further incubated with horseradish peroxidase-conjugated secondary antibody for 2 $\mathrm{h}$ at room temperature. The blot was developed using an X-ray film. Grayscale analysis of the bands was performed using ImageJ analysis software. Respective protein expression levels were normalized to that of $\beta$-actin which was used as a standard reference.

\section{Quantitative RT-PCR}

The treated and control cells were lysed using radio-immunoprecipitation assay (RIPA) buffer and their total RNAs were extracted using Trizol reagent. The cells were treated with trichloromethane $\left(\mathrm{CHCl}_{3}\right)$ and centrifuged at $16,000 \mathrm{~g}$ at $4^{\circ} \mathrm{C}$ for $20 \mathrm{~min}$ to obtain supernatant. The supernatant was then treated with isopropyl alcohol and dispersed to isolate the RNAs. Following centrifugation, the RNAs were maintained in diethyl pyrocarbonate (DEPC) water, and their concentrations determined spectrophotometrically. The RNAs were reversetranscribed to cDNAs, and the reaction was carried out at $37{ }^{\circ} \mathrm{C}$ for $20 \mathrm{~min}$ and $85{ }^{\circ} \mathrm{C}$ for 6 sec. The PCR conditions were: pre-denaturation at $95{ }^{\circ} \mathrm{C}$ for $30 \mathrm{sec}$, denaturation at $95{ }^{\circ} \mathrm{C}$ for 3 sec, annealing at $60^{\circ} \mathrm{C}$ for $34 \mathrm{sec}$, and 40 cycles. The procedure was performed in triplicates and the mean taken. Relative expression was quantified using $2^{\Delta \Delta} \mathrm{Cq}$ method, and $\beta$-actin gene was used as internal reference.

\section{Flow cytometric analysis of rh123 fluorescence}

The SC-EPN1 and SC-EPN2 cells $\left(3 \times 10^{4}\right.$ cells/well) were seeded into 96 -well plates and incubated for $24 \mathrm{~h}$. The cells were then treated with HEPES buffer containing sodium chloride $(130 \mathrm{mM})$, potassium chloride $(6 \mathrm{mM})$, magnesium sulphate $(1 \mathrm{mM})$, sodium potassium phosphate $(1.4 \mathrm{mM})$, sodium acetate $(10 \mathrm{mM})$, HEPES $(6 \mathrm{mM})$, calcium chloride $(2 \mathrm{mM})$ and glucose $(8 \mathrm{mM})$ at $37^{\circ} \mathrm{C}$. The cells were further incubated in HEPES-buffered medium supplemented with $1 \mu \mathrm{M}$ rh123. They were thereafter treated with bryostatin $(40$ and $50 \mu \mathrm{M})$ or DMSO (control group) for $72 \mathrm{~h}$, and incubated with calcium ion-free phosphate buffer containing trypsin. Trysinization was stopped by the addition of ice-cold HEPES buffer ( $\mathrm{pH} 7.4)$ containing rhl23 (1 uM) and FBS. The resultant digest was centrifuged at $1200 \mathrm{~g}\left(4^{\circ} \mathrm{C}\right)$ for $10 \mathrm{~min}$, and the cell pellets were dissolved in ice-cold HEPESbuffered solution $(2 \mathrm{ml})$. The rhl23 fluorescence was measured using a flow cytometer fitted with a 553/35 nm optical band-pass filter.

\section{Statistical analysis}

Data are expressed as mean \pm SEM, and the statistical analysis was performed using SPSS (17.0). Groups were compared using Student $t$-test. Values of $p<0.05$ were considered statistically significant.

\section{RESULTS}

\section{Expressions levels of COX-2 and IL-8 in ependymoma cells}

Table 1 shows that treatment with bryostatin significantly and dose-dependently downregulated COX-2 and IL-8 mRNAs expressions after $72 \mathrm{~h}$ of incubation $(p<0.05)$.

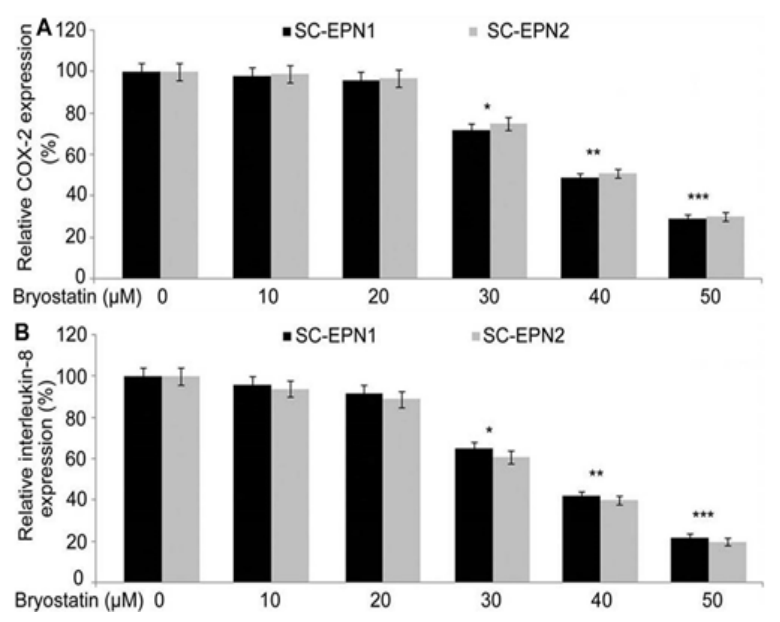

Figure 1: Effect of bryostatin on expressions of COX-2 and IL-8. A: Expression of COX-2; and B: Expression of IL-8; ${ }^{*} p<0.05,{ }^{* *} p<0.01,{ }^{* \star *} p<0.001$, compared to control group

Trop J Pharm Res, February 2019; 18(2): 253 


\section{Effect of bryostatin on cell proliferation}

The proliferations of SC-EPN1 and SC-EPN2 cells were significantly and dose-dependently inhibited by bryostatin, relative to control group ( $p$ $<0.05$ ). In SC-EPN1 cells, at 10, 20, 30, 40 and $50 \mu \mathrm{M}$ of bryostatin the percentages of cell viability were $96,81,63,42$ and $31 \%$, respectively. However, in SC-EPN2 cells the percentages of cell viability were $98,91,73,54$ and $39 \%$ at $10,20,30,40$ and $50 \mu \mathrm{M}$ of bryostatin, respectively. These results are shown in Figure 2.

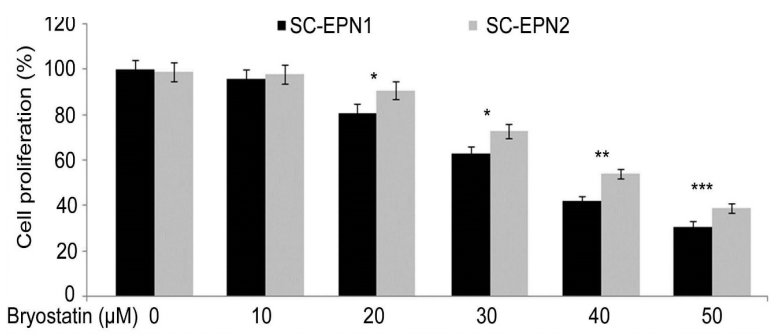

Figure 2: Effect of bryostatin on the proliferation of ependymoma cells. ${ }^{*} P<0.05,{ }^{* *} p<0.01,{ }^{* x *} p<0.001$ when compared to the control group

\section{Effect of bryostatin on cell apoptosis}

As shown in Figure 3, the extent of apoptosis was significantly higher in SC-EPN1 $(57.43 \%)$ and SC-EPN2 cells $(52.29 \%)$ than in control group $(2.37 \%, p<0.05)$.
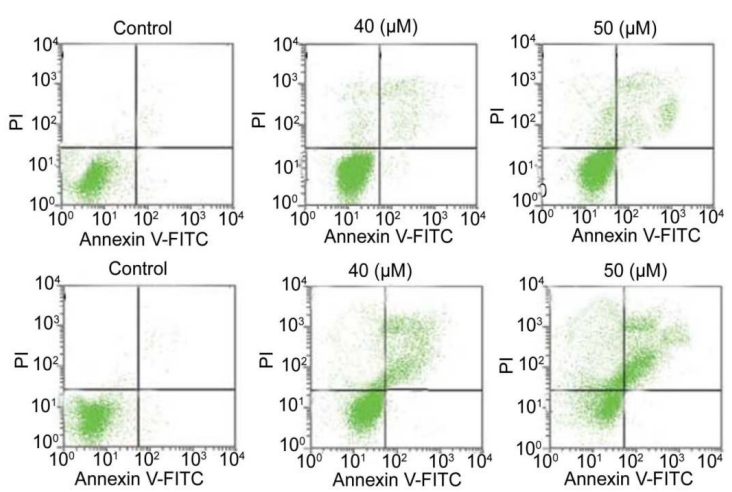

Figure 3: Effect of bryostatin on apoptosis of ependymoma cells

\section{Expressions of $\mathrm{Bcl}-2$ and $\mathrm{Bax}$}

Results from Western blotting showed that treatment with bryostatin significantly reduced the expressions of Bcl-2 in SC-EPN1 and SCEPN2 cells when compared with the control group $(p<0.05)$. However, there was no significant difference in the expression of Bax among the groups $(p>0.05)$. The results are shown in Figures $4 \mathrm{~A}$ and $4 \mathrm{~B}$ ).

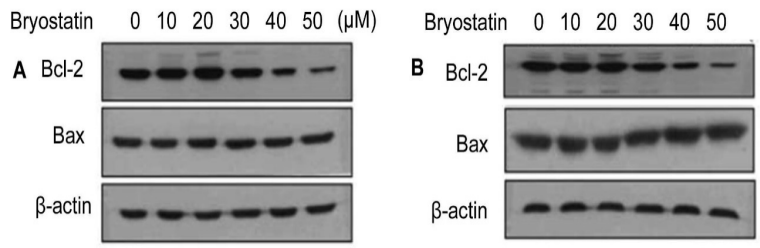

Figure 4: Effect of bryostatin on expressions of Bcl-2 and Bax. A: Expressions of Bcl-2 and Bax in SC-EPN1 cells; and $\mathrm{B}$ : Expressions of $\mathrm{Bcl}-2$ and $\mathrm{Bax}$ in SCEPN2 cells

\section{Effect of bryostatin on the expression of P- glycoprotein}

In both cancer cells, the expression of $\mathrm{P}$ glycoprotein was significantly higher in bryostatin-treated groups than in control group ( $p$ $<0.05$ ). The results of flow cytometric analysis of rh123 fluorescence showed that after $72 \mathrm{~h}$ of treatment with bryostatin $(50 \mu \mathrm{M})$, rhl23 fluorescence was significantly reduced in SCEPN1 $(8.10 \%)$ and SC-EPN2 cells $(10.11 \%)$, relative to control group $(20.83 \%, p<0.05)$. The results are shown in Figure 5.
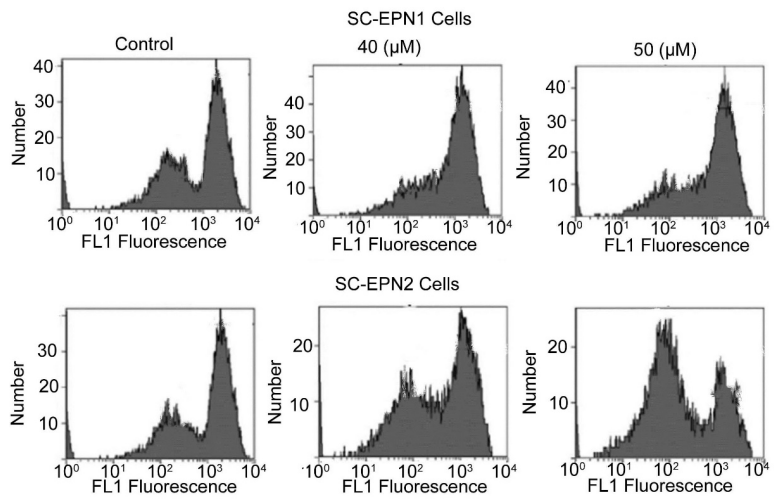

Figure 5: Expression of P-glycoprotein after treatment with bryostatin

\section{DISCUSSION}

Ependymoma, the third most commonly diagnosed brain tumor in children is characterized by poor prognosis $[3,4]$. Cyclooxygenase-2 (COX-2) possesses apoptosis-inhibitory and tumor-angiogenic properties, and so constitutes an important target in the treatment of various types of cancers $[11,12]$. In the present study, treatment with bryostatin significantly regulated COX-2 and IL-8 mRNA expressions after $72 \mathrm{~h}$ of incubation. These results suggest that bryostatin may effectively inhibit the growth and proliferation of ependymoma cells. In most brain tumors, inhibition of growth involves induction of cell apoptosis $[9,11]$. 
In this study, treatment with bryostatin led to the induction of apoptosis in ependymoma cells, an indication that bryostatin may induce apoptosis in ependymoma cells by inhibiting the expression of COX-2. High expression of COX-2 has been shown to increase the level of Bcl-2 which is an anti-apoptotic protein [13]. However, in this study, bryostatin suppressed the expression of $\mathrm{Bcl}-2$ in ependymoma cells.

Development of multi-drug resistance is presently the major factor leading to failure of chemotherapy. It has been reported that the mechanism of multi-drug resistance involves the expression of P-glycoprotein on cell membrane [14-16]. P-glycoprotein exerts its effect either by expelling the drug from the cell thereby decreasing its concentration below desired level, or by preventing the drug from entering the cell [17]. There are reports that in ependymoma cells the expression of P-glycoprotein is markedly elevated $[18,19]$. Studies have shown that expression of COX-2 is associated with the activity of P-glycoprotein [20,21].

Overexpression of COX-2 stimulates the release of prostaglandins from arachidonic acid which in turn promotes the expression of mdrlb gene. However, inhibitors of COX-2 down-regulate the expression of mdrlb gene. In a previous study, the expression of MDR1 and activity of $\mathrm{P}$ glycoprotein in glomerular mesangial cells were significantly higher than their corresponding levels in normal cells [21].

\section{CONCLUSION}

The findings of this study show bryostatin exerts anti-proliferative and apoptotic effects on ependymoma cells by suppressing COX-2 and IL-8 expressions and that treatment with bryostatin significantly reduced rh123 fluorescence. Thus, the results appear to suggest that inhibition of COX-2 expression may constitute an effective chemotherapeutic strategy for ependymoma treatment.

\section{DECLARATIONS}

\section{Acknowledgement}

The authors are highly thankful to the Head of Department of Neurosurgery for his support.

\section{Conflict of interest}

No conflict of interest is associated with this work.

\section{Authors' contribution}

We declare that this work was done by the authors named in this article and all liabilities pertaining to claims relating to the content of this article will be borne by the authors. Weiyuan Xu performed the experimental work and carried out the literature survey. Chengren Xie designed the study and wrote the paper. Yuchen Feng compiled the data and partly carried out the experimental work. All the authors approved the paper for publishing this work.

\section{REFERENCES}

1. Gjerris F, Agerlin N, Borgesen SE, Buhl L, Haase J, Klinken L, Mortensen AC, Olsen JH, Ovesen N, ReskeNielsen E, Schmidt K. Epidemiology and prognosis in children treated for intracranial tumours in Denmark 1960-1984. Childs Nerv Syst 1998; 14, 302-311.

2. Tomita T. Neurosurgical perspectives in pediatric neurooncology. Childs Nerv Syst 1998; 14: 94-96.

3. Figarella-Branger $D$, Civatte $M$, Bouvier-Labit $C$, Gouvernet J, Gambarelli D, Gentet JC, Lena G, Choux $M$, Pellissier JF. Prognostic factors in intracranial ependymomas in children. J Neurosurg 2000; 93: 605613.

4. Pollack IF, Gerszten PC, Martinez AJ, Lo KH, Shultz B, Albright $A L$, Janosky J, Deutsch $M$. Intracranial ependymomas of childhood: long-term outcome and prognostic factors. Neurosurg 1995; 37: 655-667.

5. Robertson PL, Zeltzer PM, Boyett JM, Rorke LB, Allen JC, Geyer JR, Stanley P, Li H, Albright AL, McGuireCullen $P$, et al. Survival and prognostic factors following radiation therapy and chemotherapy for ependymomas in children: a report of the Children's Cancer Group. J Neurosurg 1998; 88: 695-703.

6. Bouffet E, Perilongo G, Canete A, Massimino $M$. Intracranial ependymomas in children: a critical review of prognostic factors and a plea for cooperation. Med Pediatr Oncol 1998; 30-319-331.

7. Castelli MG, Chiabrando C, Fanelli R, Martelli L, Butti G, Gaetani P, Paoletti P. Prostaglandin and thromboxane synthesis by human intracranial tumors. Cancer Res 1989; 49: 1505-1508.

8. Kokoglu E, Tuter Y, Sandikci KS, Yazici Z, Ulakoglu EZ, Sonmez H, Ozyurt E. Prostaglandin E2 levels in human brain tumor tissues and arachidonic acid levels in the plasma membrane of human brain tumors. Cancer Lett 1998; 132: 17-21.

9. Paoletti P, Chiabrando C, Gaetani P, Castelli MG, Butti G, Martelli L, Rolli M. Prostaglandins in human brain tumors. J Neurosurg Sci 1989; 33: 65-69.

10. Pairet M, Engelhardt G. Distinct isoforms (COX-1 and COX-2) of cyclooxygenase: possible physiological and therapeutic implications. Fundam Clin Pharmacol 1996; 10: 1-17. 
11. Vane JR, Bakhle YS, Botting RM. Cyclooxygenases 1 and 2. Annu Rev Pharmacol Toxicol 1998; 38: 97-120.

12. Joki T, Heese $O$, Nikas $D C$, Bello L, Zhang J, Kraeft SK, Seyfried NT, Abe T, Chen LB, Carroll RS, Black PM. Expression of cyclooxygenase 2 (COX-2) in human glioma and in vitro inhibition by a specific COX-2 inhibitor, NS-398. Cancer Res 2000; 60: 4926-4931.

13. Matsuo M, Yonemitsu N, Zaitsu M, Ishii K, Hamasaki Y, Fukuyama K, Tabuchi K, Miyazaki S. Expression of prostaglandin $H$ synthase-2 in human brain tumors. Acta Neuropathol (Bed) 2001; 102: 181-187.

14. Patti R, Gumired K, Reddanna P, Sutton LN, Phillips PC, Reddy CD. Overexpression of cyclooxygenase-2 (COX2) in human primitive neuroectodermal tumors: effect of celecoxib and rofecoxib. Cancer Lett 2002; 180: 13-21.

15. Tsujii M, Kawano S, Tsuji S, Sawaoka H, Hori M, DuBois $R N$. Cyclooxygenase regulates angiogenesis induced by colon cancer cells. Cell 1998; 93: 705-716.

16. Tsujii M, DuBois RN. Alterations in cellular adhesion and apoptosis in epithelial cells overexpressing prostaglandin endoperoxide synthase 2. Cell 1995; 83: 493-501.

17. Endicott JA, Ling V. The biochemistry of P-glycoprotein mediated multidrug resistance. Annu Rev Biochem 1989; 58: 137-171.

18. Gottesman MM, Pastan I, Ambudkar SV. P-glycoprotein and multidrug resistance. Curr Opin Genet Dev 1996; 6: 610-617.

19. Ueda K, Cornwell MM, Gottesman MM, Pastan I, Roninson IB, Ling V, Riordan JR. The mdrl gene, responsible for multidrug-resistance, codes for $P$ glycoprotein. Biochem Biophys Res Commun 1986; 141: 956-962.

20. Henson JW, Cordon-Cardo C, Posner JB. P-glycoprotein expression in brain tumors. J Neurooncol 1992; 14: 3743.

21. Chou PM, Barquin N, Gonzalez-Crussi F, Ridaura Sanz $C$, Tomita $T$, Reyes-Mugica M. Ependymomas in children express the multidrug resistance gene: immunohistochemical and molecular biologic study. Pediatr Pathol Lab Med 1996; 16: 551-561. 